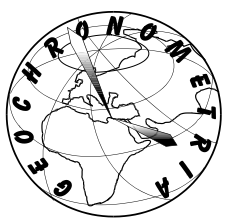

\title{
ERRATUM
}

\section{KOHONEN ARTIFICIAL NEURAL NETWORKS AND THE IndVal INDEX AS SUPPLEMENTARY TOOLS FOR THE QUANTITATIVE ANALYSIS OF PALAEOECOLOGICAL DATA}

\author{
MATEUSZ PLÓCIENNIK ${ }^{1}$, ANDRZEJ KRUK ${ }^{2}$, DANUTA J. MICHCZYŃSKA ${ }^{3}$ and H. JOHN B. BIRKS ${ }^{4}$ \\ ${ }^{I}$ Department of Invertebrate Zoology and Hydrobiology, Faculty of Biology and Environmental Protection, University of Łódź, \\ 12/16 Banacha Str., 90-237 Łódź, Poland \\ ${ }^{2}$ Department of Ecology and Vertebrate Zoology, Faculty of Biology and Environmental Protection, University of Łódź, \\ 12/16 Banacha Str., 90-237 Łódź, Poland \\ ${ }^{3}$ GADAM Centre of Excellence, Institute of Physics - CSE, Silesian University of Technology, \\ Konarskiego 22B, 44-100 Gliwice, Poland \\ ${ }^{4}$ Department of Biology, University of Bergen, PO Box 7803, N-5020 Bergen, Norway; and Environmental Change Research Centre, \\ University College London, London, WC1E 6BT, UK
}

\section{Erratum to:}

GEOCHRONOMETRIA 42 (2015): 189-201, KOHONEN ARTIFICIAL NEURAL NETWORKS AND THE IndVal INDEX AS SUPPLEMENTARY TOOLS FOR THE QUANTITATIVE ANALYSIS OF PALAEOECOLOGICAL DATA

DOI 10.1515/geochr-2015-0021

The online version of the original article can be found at: http://dx.doi.org/10.1515/geochr-2015-0021

Due to the unwitting but undoubted fault of the first and third authors, important people and institutions were omitted from our Acknowledgements. We are very grateful to Dr. Milena Obremska from Warsaw Research Center for providing unpublished palynological data (cited in the paper). This research was made possible by the support of the Institute of Geological Sciences Polish Academy of Science (ING PAN). Last but not least, we wish to express our gratitude to Professor Jacek Forysiak and Dr. Michał Słowiński for their important contribution to Rąbień mire studies used in this paper. The first and third authors sincerely apologise for this omission. 